www.jmscr.igmpublication.org

Impact Factor 5.84

Index Copernicus Value: 83.27

ISSN (e)-2347-176x ISSN (p) 2455-0450

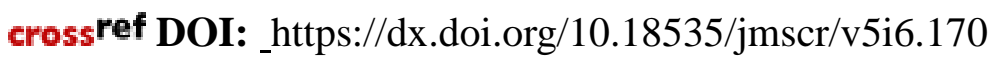

Journal Of Medical Science And Clinical Research

\title{
The Killing Power Effectiveness of Squeezed Sweet Orange Peel to the Elimination of Culex sp Mosquito Larvae
}

Authors

\author{
Agus Subagiyo, M. Choiroel Anwar, Suparmin, Marsum, Widi Hidayati ${ }^{1,2,3,4,5}$ \\ 1,2,3,4,5 Politeknik Kesehatan, Kemenkes Semarang, \\ Jl. Tirto Agung Pedalangan, Banyumanik, Semarang 50239, Indonesia
}

\begin{abstract}
Introduction: Culex sp mosquitoes with several species have been proved as vectors of disease such as West Nile Virus disease, filariasis, Japanese encephalitis (inflammation of the brain) and St Louis encephalitis. The use of natural insecticides derived from plant extracts proven to be safer because it has short residue time as, after the application, the natural insecticide will break down into compounds that are harmless to humans and the environment.

Objective: This research aims at finding out the effect and the concentration of the juice of squeezed orange peel in killing larvae of Culex sp mosquito effectively.

Methods: This research is an experiment using a Completely Randomized Design (CRD) with 4 (four) replications on each larvae test with 25 mosquitos during each treatment. To determine the different effect on each treatment, the data were analyzed by using Kruskal-Wallis test followed by Probit regression (Dose-Response Analysis) to determine the lethal concentration $50(L C)$ values in calculating the ppm (parts per million) concentration of insecticide that can lead to the elimination of $50 \%$ insect population. Result: The results of this study indicate that the sweet orange peel (Citrus sinensis) has the effect of against larvae of Culex sp instar III. The number of larvae Culex sp elimination from the application of the juice of sweet orange peel at a concentration of 1\%,2\%,3\%,4\%,5\% are 2.25, 7.25, 14.5, 21.5, 25 respectively. There are significant differences between the test group were given juice of orange peel with different concentrations.

Conclusion: The concentration of the juice of sweet orange peel (Citrus sinensis OSB) effect on mortality of larvae of Culex sp instar III during 24 hours obtained the values of $L C_{50}=2.370 \%$ and $L C_{90}=4.332 \%$. Thus, the higher the concentration of the juice of sweet orange peel, the more the number of Culex sp larvae will die.

Keywords: Juice of sweet orange peel, Larvae, Culex sp mosquitoes, Elimination.
\end{abstract}

\section{INTRODUCTION}

Diseases transmitted by mosquitoes tend to increase both from the number of patients and mortality rates. Various types of mosquitoes serve as a vector or carrier of protozoa, viruses, and not a few carriers of worm larvae can cause various diseases in humans.
Culex sp mosquitoes include insects that some of their species have been proven as vector diseases that interfere with the human life. The mosquitoes of the genus Culex sp can cause West Nile Virus, Filariasis, Japanese encephalitis, and St. Louis encephalitis. To reduce the use of synthetic insecticides, the control of larvae is conducted by 


\section{JMSCR Vol||05||Issue||06||Page 23826-23832||June}

using the vegetable insecticides. The use of natural insecticides derived from plant extracts proved to be safer because of their short residual life. After application, natural insecticides will break down into compounds that are not harmful to humans and the environment. This study aims at determining the influence and concentration of juice of sweet orange peel in eliminating the Culex sp. Mosquito larvae most effectively.

The amount of sweet orange peel (Citrus Sinensis) which is a waste from the traders of drinks made from sweet oranges can be used as a larvicidal. The content of sweet orange peel is a compound of saponin, tannin, flavonoids and essential oils that can work as toxins and cause the death of larvae so that it can be used as the community's natural larvicide.

\section{MATERIALS AND METHODS}

This research is an experiment using a Completely Randomized Design (CRD) with 4 (four) replications on each larvae test with 25 mosquitos during each treatment. To determine the different effect on each treatment, the data were analyzed by using Kruskal-Wallis test followed by Probit regression (Dose-Response Analysis) to determine the lethal concentration 50 (LC) values in calculating the ppm (parts per million) concentration of insecticide that can lead to the elimination of $50 \%$ insect population.

The hypothesis of this study is the alternative hypothesis (Ha) that is there are differences in the number of mosquito larvae in various types of squeezed juice of sweet orange peel concentration.

\section{RESULTS AND DISCUSSIONS Environmental Condition}

Measurements of the physical environment include measurement of water $\mathrm{pH}$ of test media and water temperature measurement of test media. The measurement of the physical environment is done at the time before treatment and after treatment.

Water temperatures during the study were ranged from $28-29^{\circ} \mathrm{C}$.

Table 1. Water temperature measurements before and after treatment

\begin{tabular}{|c|c|c|c|c|c|c|c|c|c|c|c|}
\hline \multirow{2}{*}{ No } & \multirow{2}{*}{ Group Treatment } & \multicolumn{5}{|c|}{ Before Treatment $\left({ }^{0} \mathrm{C}\right)$} & \multicolumn{5}{|c|}{ After Treatment $\left({ }^{0} \mathrm{C}\right)$} \\
\hline & & A1 & $\mathrm{A} 2$ & A3 & A4 & $?$ & A1 & $\mathrm{A} 2$ & A3 & A4 & $?$ \\
\hline 1. & G- $(0 \%)$ & 28 & 28 & 28 & 28 & 28 & 28 & 28 & 28 & 28 & 28 \\
\hline 2. & $\mathrm{~T} 1(1 \%)$ & 29 & 28 & 29 & 28 & 28.5 & 29 & 28 & 29 & 28 & 28.5 \\
\hline 3. & $\mathrm{~T} 2(2 \%)$ & 29 & 28 & 29 & 28 & 28.5 & 29 & 28 & 29 & 28 & 28.5 \\
\hline 4. & $\mathrm{~T} 3(3 \%)$ & 28 & 28 & 29 & 28 & 28.25 & 28 & 28 & 29 & 28 & 28.25 \\
\hline 5. & $\mathrm{~T} 4(4 \%)$ & 28 & 28 & 28 & 28 & 28 & 28 & 28 & 28 & 28 & 28 \\
\hline \multirow[t]{3}{*}{6.} & $\mathrm{~T} 5(5 \%)$ & 28 & 28 & 29 & 28 & 28.25 & 28 & 28 & 29 & 28 & 28.25 \\
\hline & Minimum & \multicolumn{5}{|c|}{28} & \multicolumn{5}{|c|}{28} \\
\hline & Maximum & \multicolumn{5}{|c|}{29} & \multicolumn{5}{|c|}{29} \\
\hline
\end{tabular}

Table 1 shows the water temperature of the test media before being treated in the treatment and controlled group was $28.25{ }^{\circ} \mathrm{C}$ in average with the lowest temperature was $28^{\circ} \mathrm{C}$ and the highest temperature was $29^{\circ} \mathrm{C}$. The water temperature of the larval development site on the experimental media after the treatment showed no change. These results indicate that the water temperature at which the development of the larvae before and after the treatment given did not show any change. Water temperature under these conditions is a good condition for the proliferation of larvae.

Measurement of $\mathrm{PH}$ water of the test media is carried out before and after the treatment. Water $\mathrm{pH}$ at the time of the study was ranged from 7-8. 
Table 2. Results of PH measurements of water before and after treatment

\begin{tabular}{|l|c|c|c|c|c|c|c|c|c|c|c|}
\hline \multirow{2}{*}{ No. } & \multirow{2}{*}{$\begin{array}{c}\text { Group } \\
\text { Treatment }\end{array}$} & \multicolumn{4}{|c|}{ PH Before Treatment } & \multicolumn{5}{c|}{ PH After Treatment } \\
\cline { 3 - 15 } & A1 & A2 & A3 & A4 & $?$ & A1 & A2 & A3 & A4 & $?$ \\
\hline 1. & G- (0\%) & 7 & 7 & 7 & 7 & 7 & 7 & 7 & 7 & 7 & 7,5 \\
\hline 2. & T1 (1\%) & 7 & 7 & 7 & 7 & 7 & 7.5 & 7.5 & 7.5 & 7.5 & 7.5 \\
\hline 3. & T2 (2\%) & 7 & 7 & 7 & 7 & 7 & 7.5 & 7.5 & 7.5 & 7.5 & 7.5 \\
\hline 4. & T3 (3\%) & 7 & 7 & 7 & 7 & 7 & 8 & 8 & 8 & 8 & 8 \\
\hline 5. & T4 (4\%) & 7 & 7 & 7 & 7 & 7 & 8 & 8 & 8 & 8 & 8 \\
\hline 6. & T5 (5\%) & 7 & 7 & 7 & 7 & 7 & 8 & 8 & 8 & 8 & 8 \\
\hline & Rata-rata & & 7 & & & & 7,65 & \\
\hline & Minimal & & 7 & 7 & & & & & \\
\hline
\end{tabular}

Table 2 shows the $\mathrm{pH}$ of the water of the test media before being treated in the treatment and controlled group obtained the average water $\mathrm{pH}=$ 7. The water $\mathrm{pH}$ of the larval development site after the average treatment was 7.65. The highest $\mathrm{pH}$ on the test medium occurred in the fourth repetition $=8$. The results showed the change of the $\mathrm{pH}$ of the water in the development site of the larvae before andafter the treatment. The change is due to the influence of the squeezed orange peel skin intervention but the condition is still normal for the proliferation of larvae.

The environment is one of the most important roles for the survival of Culex sp. Some environmental factors, such as the temperature and acid-base of the larvae live, will indirectly affect the population of Aedes aegypti mosquitoes (Sucipto, 2011). Therefore it is necessary to measure the physical environment in doing this research, to find out how big the role of the environment in the research results.

Number of Culex sp Larvae Deaths on Various Concentrations After 24 Hours Treatment

Prepared media for experiments containing Culex sp larvae were then treated with various concentrations of squeezed orange peel juice of $1 \%, 2 \%, 3 \%, 4 \%, 5 \%$, which were then observed during 24 hours. Larvae that look inactive and when being touched using a stick were not moving during the calculation is considered dead.

Table 3. Toxicity Test of Orange Peel to Culex sp Larvae Mortality

\begin{tabular}{|l|c|c|c|c|c|c|c|}
\hline \multirow{2}{*}{$\begin{array}{l}\text { Concentration } \\
(\%)\end{array}$} & \multirow{2}{*}{$\begin{array}{l}\text { Number of } \\
\text { Mosquito }\end{array}$} & \multicolumn{4}{|c|}{$\begin{array}{l}\text { Number of Larvae Death } \\
\text { on each replication }\end{array}$} & \multicolumn{2}{c|}{ Average } \\
\cline { 3 - 8 } & & 1 & 2 & 3 & 4 & $\sum$ & $\%$ \\
\hline G - & 25 & 0 & 0 & 0 & 0 & 0 & $0 \%$ \\
\hline T1 (1\%) & 25 & 2 & 2 & 3 & 2 & 2.25 & $9 \%$ \\
\hline T2 (2\%) & 25 & 8 & 6 & 7 & 8 & 7.25 & $29 \%$ \\
\hline T3 (3\%) & 25 & 13 & 15 & 15 & 15 & 14.5 & $58 \%$ \\
\hline T4 (4\%) & 25 & 21 & 21 & 22 & 22 & 21.5 & $86 \%$ \\
\hline T5 (5\%) & 25 & 25 & 25 & 25 & 25 & 25 & $100 \%$ \\
\hline
\end{tabular}




\section{JMSCR Vol||05||Issue||06||Page 23826-23832||June}

Based on the data in Table 3 it can be seen that in the negative control group no larval mortality was found in all replications. In the treatment group, the lowest average larval mortality was found at $1 \%$ concentration $(9 \%)$, while the highest larval mortality rate was found at the concentration of $5 \%(100 \% 0$. Based on the number of larvae deaths in each treatment, the number can be seen in the following graph.

Figure 1. The average death of larvae due to the squeezed juice of sweet orange peel From the graph, it is obvious that the higher concentration of squeezed juice of orange peel

\section{The average death of larvae}

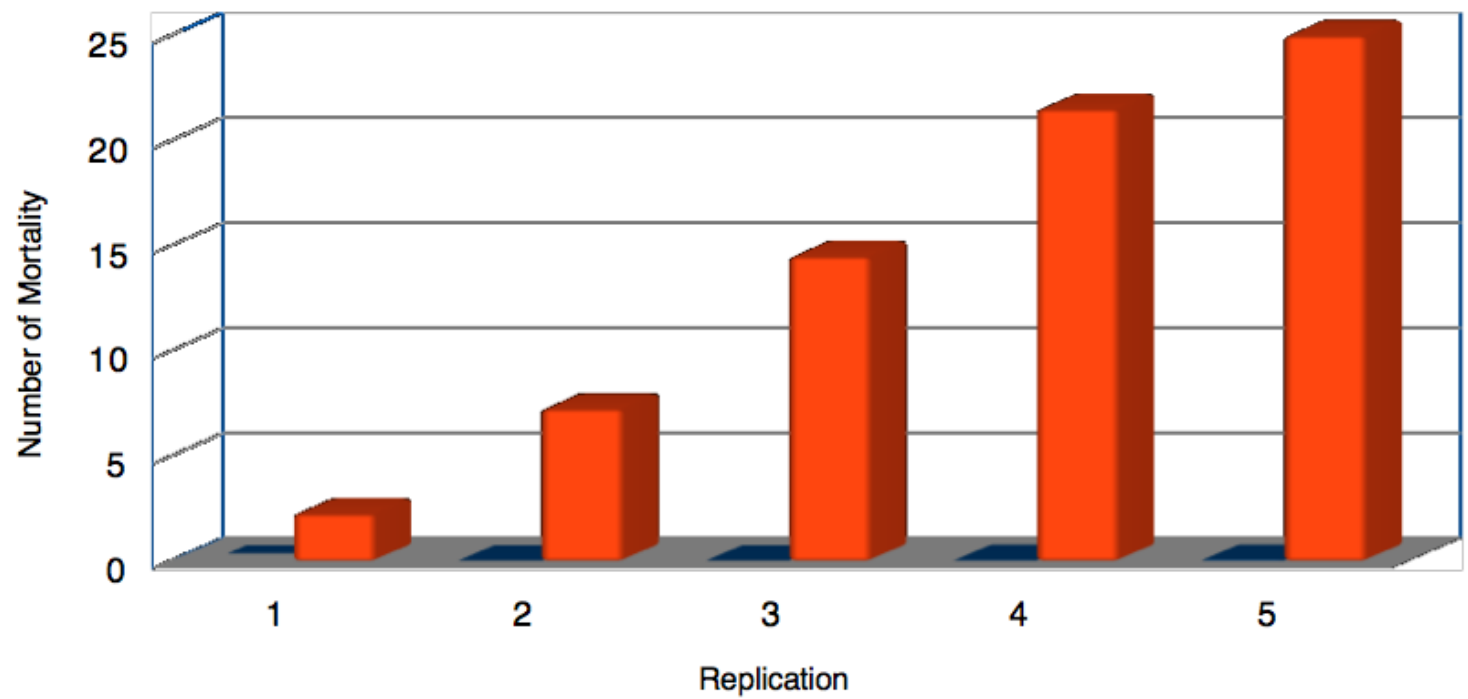

(Citrus sinensis $O S B$ ), the higher the average mortality rate of Culex sp larvae.

Effect of the Concentration of The Squeezed Juice of Sweet Orange Peel in Eliminating Mosquito Larvae

The results showed that all the concentration of squeezed juice of sweet orange peel (Citrus sinensis OSB) can cause the death of Culex sp larvae. The greater the concentration, the more the number of the dead larvae. From these observations, the results of this study can be applied in the community by calculating the needs of the juice which will be used by adjusting the media to be treated. The Kruskal-Wallis test was performed to determine whether there was a significant difference in an average number of larval mortality in each treatment group. The results of Kruskal-Wallis test are presented in the following table:

Table 5. Differences in Larva Deaths At All Concentrations

\begin{tabular}{|l|c|c|}
\hline Concentration & Mean & P value \\
\hline C- $(0 \%)$ & 2.50 & 0.000 \\
\hline $1 \%$ & 6.50 & \\
\hline $2 \%$ & 10.50 & \\
\hline $3 \%$ & 14.50 & \\
\hline $4 \%$ & 18.50 & \\
\hline $5 \%$ & 22.50 & \\
\hline
\end{tabular}




\section{JMSCR Vol||05||Issue||06||Page 23826-23832||June}

The data obtained from the Kruskal-Wallis test showed a $\mathrm{p}$ value $<0.05$ which means that there is a significant difference in the number of dead larvae between concentrations. This way, the alternate hypothesis is accepted as there are at least two groups of orange peel juice concentrations that have a significant difference in an average number of larvae deaths.

To determine the concentration of sweet orange peel juice required to turn off $50 \%$ (LC50) and 90\% (LC90) Culex sp larvae for 24 hours, a probit analysis was performed. From the result of calculation, the result of LC50 concentration is at 2.370 and LC90 is at concentration of 4.332 .

According to WHO, larvacide concentrations are considered effective when it can cause the death of the intermediate test larvae $10-95 \%$ which will be used to find the lethal concentration. The value of LC selected in this study Is LC 50. This is due to the level of insecticide concentration is considered as having a good killing power and is not harmful to the environment when reaching LC 50. LC value below LC 50 is categorized as having low killing power, and LC values above LC 50 are categorized as having an effective killing power. For insecticides capable of achieving LC above LC50 requires testing to determine the level of security towards environmental sustainability ( Ahdiyah \&Purwani, 2015).

Based on this it can be seen that the squeezed juice of sweet orange peel is included in toxic criteria. This is consistent with Avents et.al (2011) opinion, that acute toxicity said to be highly toxic is in the range of $<1 \%$, toxic $1-10 \%$, $10-50 \%$ toxic, slightly toxic $50-99 \%$ and nontoxic in the range of $100 \%$.

Based on the results of probit analysis can be seen that the higher the concentration of the squeezed juice of sweet orange peel juice, the more the number of Culex sp larvae are dead. The ability of larvacide from squeezed juice of sweet orange peel is produced from several chemical compounds inside the plant. The phytochemicals in the orange peel are tannins, saponins, flavonoids, and limonoids.

The Effect of Squeezed Juice of Sweet Orange Peel Against Larvae Culex sp Morphology

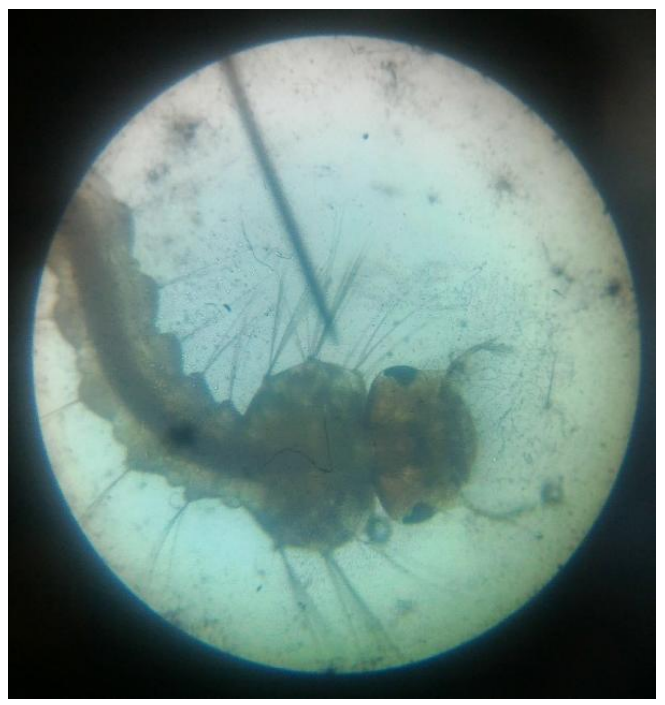

A

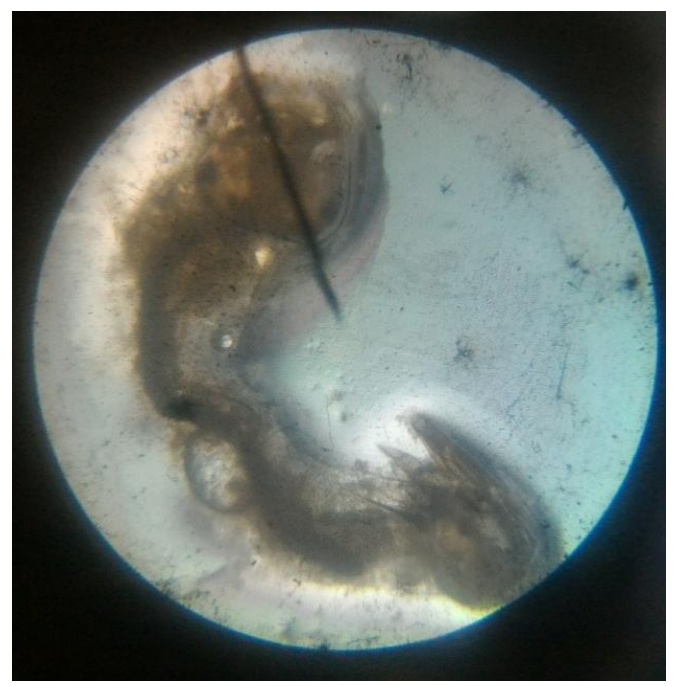

B

Figure 2. Comparison of control group larvae with larvae exposed to the squeezed juice of sweet orange peel

Notes: A. Healthy Culex sp larvae; B. Culex sp larvae after exposure to sweet orange peel juice for 24 hours. 


\section{JMSCR Vol||05||Issue||06||Page 23826-23832||June}

Based on the above picture, it can be seen the prominent difference between Culex sp larvae control group (A) with Culex sp larvae exposed to the juice of orange peel (B). In figure $B$, the damage can be seen in hair loss and damaged skin. The damage is suspected as a result of the larvacide effect of the compound from the juice of sweet orange peel. The larvae body also becomes soft after being exposed to the squeezed juice. The morphological differences of Culex sp larvae are caused by the content of the compounds in the orange peel which include Tannin, Saponin, Flavonoid, Limonoid.

Tannin is a "phenolic compounds" that can precipitate proteins. Tannin can reduce the ability to digest food by reducing the activity of digestive enzymes (proteases and amylases) and interfere with intestinal protein activity. The larval response to these compounds is the decrease of growth rate and nutritional disorder (Dinata, 2008).

Tannin can enter the body of the larvae in two ways: by penetrating the body wall of the larvae and entering through the digestive tract. Tannin that penetrates the larval body wall can affect muscle activity causing muscle weakness. Saponins can cause the death of larvae by interacting with the larval cuticle membrane and destroying the membrane (Lisqorina \& Natalia, 2013).

The larvae can not synthesize cholesterol, but the substance is needed by the larvae in the ecdysone biosynthesis - the hormone needed in the larval skin replacement. The formation of complexes with saponins causes the cholesterol not to be absorbed strongly by the larval digestive system. The mechanism of formation of cholesterol and saponin complex that occurs is a chemical reaction between saponin aglycon and lipophilic cholesterol site. Such reactions lead to the formation of micelles or spherical structures between cholesterol and saponin molecules. This causes an interruption at the stage of larval skin replacement (Lisqorina \& Natalia, 2013)

Flavonoids work as respiratory inhibitors. Flavonoids enter the body of the larvae through the respiratory system which will then cause weakness in the nerves as well as damage to the respirator and cause the larvae can not breathe. As a result of the entry of flavonoid compounds through the siphon, it causes the damage to siphon so that the larvae should align its position with the water surface to facilitate the oxygen taking (Lisqorina \& Natalia, 2013).

The cause of weakness in nerves caused by flavonoids is the inhibition of acetylcholinesterase enzyme work. Acetylcholine formed by the central nervous system serves to deliver impulses from nerve cells to muscle cells. After the impulse is delivered, the process is stopped by the acetylcholinesterase enzyme that breaks acetylcholine into acetyl ko-A and choline. The presence of flavonoids will inhibit the operation of this enzyme resulting in accumulation of acetylcholine which will cause disturbances in the impulse delivery system to the muscles that can result in muscle spasms, paralysis and ends in death (Lisqorina \& Natalia, 2013).

In addition, limonoid can enter the body of the larvae through the skin or body wall by osmosis because the skin or larval body wall is permeable to the compound being passed. The limonoid will enter the epidermal cells that always undergo division in the process of skin change so that the epidermal cells are paralyzed and eventually the larvae will die (Utariningsih \& Purwanti, 2010).

\section{CONCLUSION}

The results of the study conclude that:

- Squeezed juice of sweet orange peel has a larvicidal effect on Culex sp instar III larvae.

- The number of deaths of Culex sp larvae due to the administration of sweet orange peel juice at concentrations of $1 \%, 2 \%$, $3 \%, 4 \%, 5 \%$ are $2.25,7.25,14.5,21.5$, and 25 consecutively.

- There are significant differences between test groups given the orange peel juice with different concentrations.

- The concentration of sweet orange peel juice effect on mortality of Culex sp instar 
III larvae for 24 hours with LC50 is $2.370 \%$ and with LC90 is $4.332 \%$.

- The higher the concentration of the squeezed juice of sweet orange peel, the higher the number of Culex sp larvae will die.

\section{ACKNOWLEDGEMENT}

This research is funded by Poltekkes Kemenkes Semarang 2016. On this occasion, the researcher would like to thank Director of Poltekkes Kemenkes Semarang as well as Research and Community Empowerment Unit of Poltekkes Kemenkes Semarang which have funded and facilitated the research, Research and Health Development Agency of Ciamis as a place of research which has helped with data retrieval activities.

\section{REFERENCES}

1. Ahdiyah, I. and Purwani, K.I., 2015. Pengaruh Ekstrak Daun Mangkokan (Nothopanax scutellarium) Sebagai Larvasida Nyamuk Culex sp.

2. Avent, M.L., Rogers, B.A., Cheng, A.C. and Paterson, D.L., 2011. Current use of aminoglycosides: indications, pharmacokinetics, and monitoring for toxicity. Internal medicine journal, 41(6), pp.441-449.

3. Dinata, A., 2008. Basmi Lalat dengan Jeruk Manis. Litbang pemberantasan penyakit Bersumber Binatang. Balitbang kesehatan depkes RI. Ciamis www. litbang. depkes. go. id .

4. Lisqorina, Pratiwi, L, Natalia D. 2013. Uji Aktivitas Ekstrak Etanol Daun Senggani (Melastoma malabathricum 1) Sebagai Larvasida Aedes aegypti.

5. Sucipto, C.D., 2011. Vektor penyakit tropis. Yogyakarta: Gosyen Publishing.

6. Utariningsih, D. and Purwanti, D., 2010. Pemanfaatan Daun Jeruk Nipis (Citrus aurantifolia) sebagai Larvasida untuk Pemberantasan Nyamuk Aedesaegepty. 